\title{
Brackish-water submergence of the common periwinkle, Littorina littorea, and its digenean parasites in the Baltic Sea and in the Kattegat
}

\author{
G. Lauckner \\ Biologische Anstalt Helgoland (Litoralstation); \\ D-2282 List/Sylt, Federal Republic of Germany
}

\begin{abstract}
North Sea and Baltic Sea populations of Littorina littorea differ with respect to their vertical distribution. In the North Sea $L$. littorea is strictly intertidal while in the Baltic Sea maximum population densities occur in the sublittoral. Levels of infestation with larval digenetic trematodes diminish qualitatively (number of species recorded) and quantitatively (number of hosts infested) with decreasing salinity. Both the host and two parasite species - Cryptocotyle lingua and Microphallus pygmaeus - display 'brackish-water submergence' under conditions of reduced surface salinity.
\end{abstract}

\section{INTRODUCTION}

'Brackish-water submergence' is a term coined by Remane $(1940,1955)$ to describe the extension or downward displacement of the vertical distributional range of marine species penetrating into waters characterized by a vertical salinity gradient. Such conditions are encountered in the Baltic Sea.

Littorina littorea, which in the North Sea occurs intertidally, extends its bathymetric range in the Baltic into the sublittoral. The vertical distribution of the periwinkle in the Baltic is imperfectly known; there are only a few scattered records of its relative abundance in that area. No quantitative information is thus far available on the trematode fauna of Baltic Sea periwinkles.

The present studies were initiated in 1973 after an inquiry of a baby food factory complaining about conspicuous dark spots of presumed parasitic origin in the skin of Baltic Sea cod used in the production of baby food. These spots were identified by the author as the encysted metacercariae of the heterophyid trematode Cryptocotyle lingua. Concomitant inspection of several species of round- and flatfish landed by Baltic Sea fishermen revealed $C$. lingua infestations which were considerably heavier than those observed in North Sea fish. It was concluded that the ecological conditions prevailing in the Baltic Sea are particularly favourable for the completion of the life cycle of this digenean. Therefore, studies were concentrated on its first intermediate host, L. littorea. Subsequently, these studies were extended into a general survey of the trematode fauna of $L$. littorea in the Baltic Sea and the transition area Sound, Belts and Kattegat. 


\section{MATERIALS AND METHODS}

In the Baltic proper, surface samples of Littorina littorea were obtained from rocks and algal vegetation between the upper limit of the vertical distributional range of the species (which is congruent with the littoral fringe in the tideless parts of the Baltic) and a depth of approximately $30 \mathrm{~cm}$. In the transition area, surface samples were collected between the upper limit (i.e. the supralittoral splash zone) and the low-water mark. Sublittoral samples were hand-collected during SCUBA dives. All samples were transferred to the laboratory and processed as outlined by Lauckner (1984).

\section{RESULTS}

Along the coastline from the northern Kattegat to Lübeck Bay in the southwestern Baltic Sea there is a gradual shift of the vertical distributional range and the abundance maximum of Littorina littorea from the intertidal to the subtidal zone - a phenomenon described as 'brackish-water submergence' (Remane, 1940, 1955). As in the Baltic proper there are no lunar tides; changes in the water level depend mainly on wind action, occur irregularly and are generally negligible. As a consequence, there is a marked decrease in the population density of the periwinkles along the littoral fringe toward the southern parts of the German Baltic Sea coast.

Of the 6 trematode species parasitizing L. littorea in the North Sea (Werding, 1969; Lauckner, 1980, 1984), only 5 follow their host into the Kattegat, and only 4 have as yet

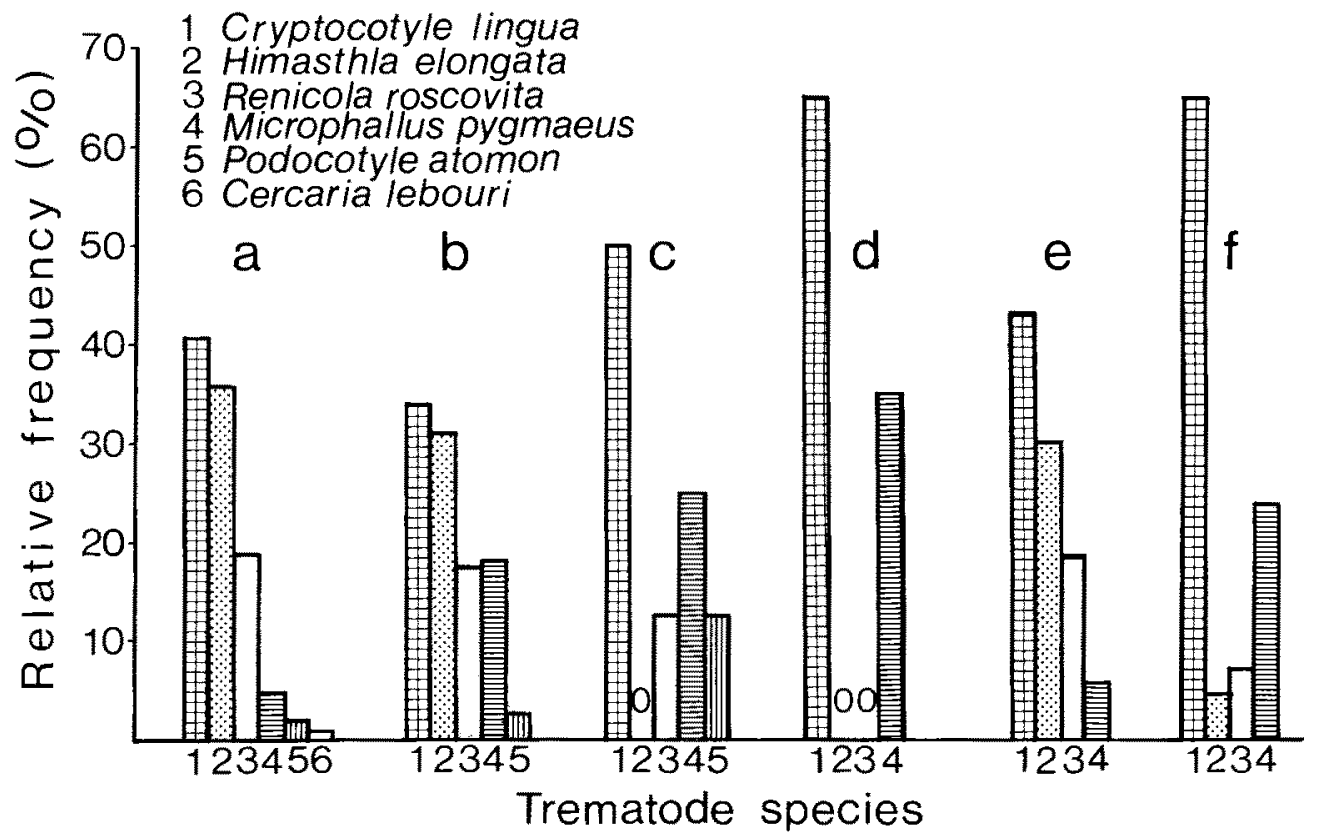

Fig. 1. Littorina littorea. Relative frequencies of larval trematode infestation in hosts from different stations/areas: $a=$ North Sea (surface samples), $b=$ Baltic Sea and Kattegat (surface samples), $c=$ southwestern Baltic Sea (surface samples), d = Bay of Neustadt (deep-water sample) e $=$ Bay of Arhus (surface samples), f = Sletterhage Lighthouse (southern Kattegat; deep-water sample) 


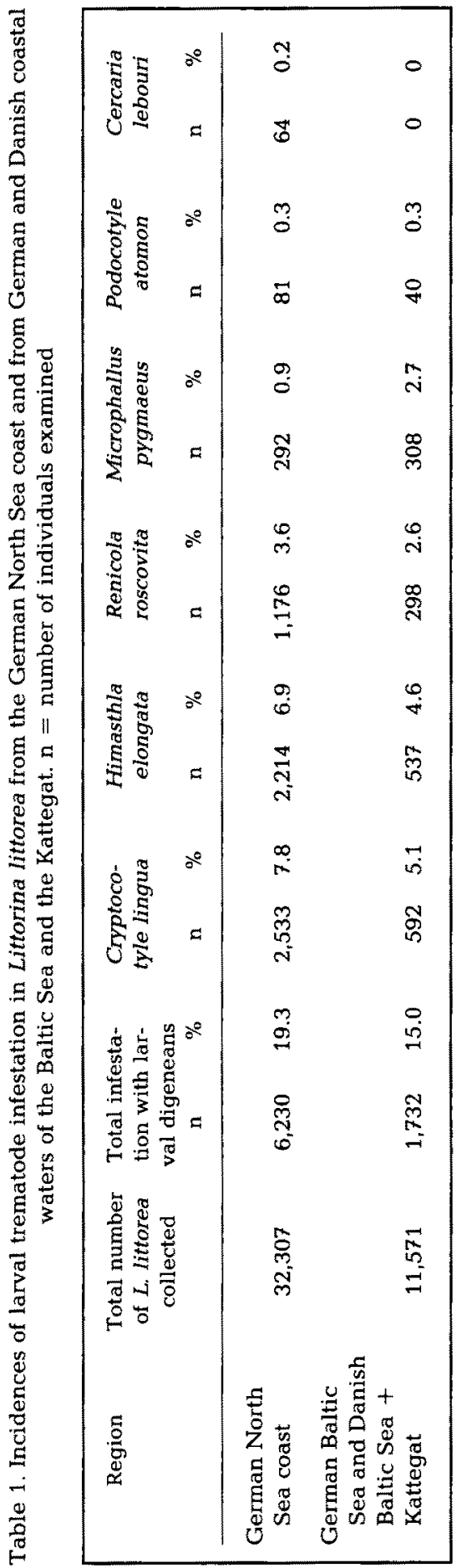


been observed south of the Flensburg Fjord. Himasthla elongata, next to Cryptocotyle lingua the most prevalent species in North Sea and Kattegat littorines (Table 1), is absent from periwinkles occurring south of Fehmarn. While the relative abundance of $C$. lingua, $H$. elongata, Renicola roscovita and Podocotyle atomon in L. littorea from the North Sea (Fig. 1a) and from the Baltic plus Kattegat shows little variation, Microphallus pygmaeus occurs significantly more frequently in hosts from the latter region (Fig. 1b).

Concomitantly with a decrease in the population density of near-surface littorines toward the inner parts of the Baltic, there is a distinct decline of trematode infestations in hosts living in shallow water, accompanied by a drastic change in the relative composition of the parasite spectrum (Fig. 1C). Along the coast of Neustadt Bay (from approximately $54^{\circ} 4^{\prime} \mathrm{N} 10^{\circ} 46^{\prime} \mathrm{E}$ to $53^{\circ} 57.5^{\prime} \mathrm{N} 10^{\circ} 52^{\prime} \mathrm{E}$ ), $C$. lingua, $R$. roscovita, $M$. pygmaeus and $P$. atomon occur in low abundance in littorines from the surface. Prevalences were $0.8 \%$ for $C$. lingua, $0.4 \%$ for $M$. pygmaeus, $0.2 \%$ for $R$. roscovita and $0.2 \%$ for $P$. atomon in a series of samples comprising a total of $471 \mathrm{~L}$. littorea. In contrast, 108 of 577 periwinkles recovered from rocks and boulders in the middle of Neustadt Bay $\left(54^{\circ} 01^{\prime} 04^{\prime \prime} \mathrm{N} 10^{\circ} 50^{\prime} 04^{\prime \prime} \mathrm{E}\right)$ at $16 \mathrm{~m}$ depth, were found to harbour larval trematodes. Of these, $64.9 \%$ were C. lingua and $35.1 \%$ M. pygmaeus (Fig. 1d). No stages of the other digeneans present in surface littorines from that area $-R$. roscovita and $P$. atomon-were found.

Similarly, of 334 deep-water littorines collected off Sletterhage Lighthouse (Danish coast of southern Kattegat; $56^{\circ} 5.6^{\prime} \mathrm{N} 10^{\circ} 30.8^{\prime} \mathrm{E}$ ) between 20 and $26 \mathrm{~m}$ depth, $12.6 \%$ were infested with larval digeneans representing 4 species. $64.3 \%$ were $C$. lingua, $23.8 \% \mathrm{M}$. pygmaeus, $7.1 \% R$. roscovita and $4.8 \% H$. elongata (Fig. 1f). Surface samples from the same area ( ( rhus Bay; along the coast from approximately $56^{\circ} 10.6^{\prime} \mathrm{N} 10^{\circ} 14.0^{\prime} \mathrm{E}$ to $56^{\circ} 7.3^{\prime} \mathrm{N} 10^{\circ} 33.8^{\prime} \mathrm{E}$ ), comprising a total of 3,181 L. Littorea, exhibited a parasite spectrum (Fig. 1e) similar to that of North Sea littorines (Fig. 1a) but very different from that of deep-water periwinkles (Fig. 1d, f).

\section{DISCUSSION}

Similar to the ecological response of free-living marine euryhaline invertebrates to vertical salinity gradients, the downward displacement of the abundance maximum of euryhaline digenean parasites occurring under identical conditions may be interpreted as brackish-water submergence. However, the conclusion that salinity is the sole or main factor determining this shift, seems to be premature or may even turn out to be erroneous. At least the synergistic effects of salinity and temperature must be considered. Moreover, life cycle peculiarities may be complicating, or possibly decisive, factors determining the ecological success of a marine parasite in an environment with reduced salinity. If, for example, the first and the second intermediate hosts differ with respect to their euryhalinity, they may occupy identical microhabitats in sea water of oceanic salinity but different microhabitats in brackish water. The resultant spatial separation of first and second intermediate hosts may lead to a disruption of the parasite's life cycle. A similar situation arises when the second intermediate host becomes inaccessible to the final host, for example by brackish-water submergence of the former.

Of the 4 larval digeneans accompanying Littorina littorea into the southern Baltic 
Sea, only Cryptocotyle lingua and Microphallus pygmaeus display distinct brackishwater submergence. Both are bird trematodes but differ with respect to their life-cycle pattern. C. lingua has a normal 3-host cycle; its metacercariae develop in fishes. $M$. pygmaeus has an abbreviated life cycle; its cercariae transform directly into metacercariae within the sporocysts in L. littorea. For the completion of the cycle of this digenean, an infested periwinkle must be swallowed by a compatible bird host. Suppression of the free-swimming cercarial stage as in $M$. pygmaeus may be interpreted as an adaptation to brackish-water conditions (Reimer, 1964). The relative increase in abundance of this species in surface littorines from the Baltic Sea (Fig. 1b, c) favours this view.

At first sight, the occurrence of the larval stages of bird trematodes in deep-water littorines is surprising and would appear to be disadvantageous for the parasite from the standpoint of the completion of its life cycle. However, the magnitude of C. lingua metacercarial infestation in demersal fish from the Baltic Sea (Möller, 1974, 1975a, b; Lauckner, pers. obs.), together with the prevalence levels of the adult worms in Baltic larids (Guildal, 1964, 1968; Lauckner, pers. obs.), indicates that this digenean is highly successful in brackish water. Möller (1975b) found more than $98 \%$ of 926 Gadus morhua, caught in 1 to $3 \mathrm{~m}$ depth in the Kiel Fjord, to be infested with up to 500 metacercariae. Infestation levels are usually higher in fish from deeper water. Thus, the number of encysted larvae visible beneath the skin of a heavily infested $38 \mathrm{~cm}$ long cod caught of Schleimünde (western Baltic Sea) at $15 \mathrm{~m}$ depth was estimated to be in the range of some 38,000 to 40,000 . Similar levels of $C$. lingua infestation have previously only been reported by Linton (1940), who counted a total of 76,800 metacercariae in a $32 \mathrm{~cm}$ long window-pane flounder Lophopsetta maculata from the US Atlantic coast.

Although gadoids and pleuronectids migrate between deep and shallow water, they presumably acquire major $C$. lingua infestations in deep water. Since lower temperature and higher salinity distinctly prolong the survival time of $C$. lingua cercariae, the conditions prevailing at greater depths increase the chance of the cercariae to reach a fish host. Sindermann \& Farrin (1962) have shown that cercarial emergence from $L$. littorea decreases significantly at salinities below $18 \% \mathrm{~S}$. Hence, the number of cercariae liberated by the first intermediate host in high-salinity bottom water of the Baltic Sea may be higher than near the surface, provided that the temperature is not too low to preclude cercarial emergence and invasive activity.

The cercaria of Cryptocotyle is a good swimmer. It has two conspicuous eye spots and is positively phototactic under normal underwater light conditions. Therefore, cercariae emerging from Littorina in sea water of full salinity usually swim upward and invade pelagic fish. This behaviour is advantageous for the species because fishintermediate hosts living near the surface are more easily accessible to the bird-final host. Sindermann \& Rosenfield (1954) and Sindermann \& Farrin (1962), for example, state that herring and other inshore marine fish from the New England coast are often liberally speckled with the black spots forming around the encysted metacercariae.

The fact that $C$. lingua is distinctly euryhaline and has a large survival and invasive capacity, also in brackish water, has been demonstrated by Stunkard \& Shaw (1931), Reimer (1970) and Möller (1978) and has been confirmed by the present author's laboratory studies. Reimer (1970) observed spontaneous emergence of $C$. lingua cercariae in water of $8.1 \% \mathrm{~S}$, and Möller (1978) showed that the cercariae are invasive at 
salinities as low as $4 \% \mathrm{~S}$. However, when suspended in stratified water with a salinity of $60 \% \mathrm{~S}$ at the bottom and $10 \% \mathrm{~S}$ at the top, $C$. lingua cercariae, although being distinctly euryhaline, tend to concentrate in the $30 \% \mathrm{~S}$ layer. When suspended in water of $15 \% \mathrm{~S}$, they do not swim to the surface but aggregate at the bottom of the container. When this happens in nature in the Baltic, the cercariae have an increased chance of encountering bottom-dwelling fish.

The tendency of the cercariae to stay near the sea bottom may be even more pronounced at still lower salinities. The body fluids of $L$. littorea are nearly isosmotic at salinities down to approximately $15 \% \mathrm{~S}$ but then become progressively hyperosmotic (Todd, 1964; Rumsey, 1973). Hence, cercariae shed by periwinkles living in water of less than $15 \% \mathrm{~S}$ are submitted to an osmotic shock upon emergence from the host. This may increase their tendency to remain near the bottom.

Similar to $C$. lingua, M. pygmaeus has a broad final-host spectrum; it has been reported from a number of Charadriiformes and Anseriformes (Levinsen, 1881; Jägerskiöld, 1900; Deblock \& Tran Van Ky, 1966; James, 1968). Although diving ducks in the Baltic are potentially capable of acquiring $M$. pygmaeus by feeding on $L$. littorea from greater depths, this route of infestation appears to be highly improbable from the standpoint of energy expenditure because the birds can obtain plenty of food - mussels, cockles and also littorines - from shallow water. Therefore, infestation of deep-water littorines with $M$. pygmaeus beyond doubt represents a dead-end road in the life cycle of this trematode.

In the case of $C$. lingua and $M$. pygmaeus, $L$. littorea acquires an infestation by devouring embryonated eggs. The miracidia of these species hatch in the alimentary tract of the prosobranch host. In contrast, Himasthla elongata has a free-swimming miracidium which must actively invade a periwinkle. The absence of $H$. elongata from surface-dwelling littorines south of Fehmarn may directly be related to adverse effects of lowered salinity on the miracidium. In deep water, where salinity would be suitable for miracidial development, excessively low temperatures may be the limiting factor. The further life-cycle stages of $H$. elongata are less sensitive to lowered salinity. Thus, littorines infested with the rediae of this species can be maintained at salinities of less than $15 \%$ S for extended periods of time, and cercariae experimentally induced to encyst in vitro survive equally well at salinities of $30 \%, 15 \%$ and $10 \% \mathrm{~S}$ (Lauckner, pers. obs.).

Renicola roscovita occurs in surface-dwelling $L$. littorea south of Fehmarn but not in deep-water individuals from the same area. As in C. lingua and M. pygmaeus, there is no free-swirnming miracidial stage in this species - a fact which, apparently, enables $R$. roscovita to penetrate far into brackish water. The absence of Renicola infestations from deep-water littorines at stations where the parasite occurs in surface samples of $L$. littorea may be explained by the pronounced positive buoyancy of the egg, which makes deep-water hosts inacessible to the invasive stage.

As for M. pygmaeus, brackish-water submergence would be of little or no advantage for the completion of the life cycles of $R$. roscovita and $H$. elongata. Both species utilize (virtually non-motile) bivalves as second intermediate hosts which, in a tideless area, are inaccessible to the final host.

At first sight, the absence of Podocotyle atomon - the sole fish trematode which utilizes $L$. littorea as first intermediate host - from deep-water littorines in an area where it occurs in low-salinity surface waters appears to be somewhat puzzling. In Neustadt 
Bay, for example, the entire array of hosts necessary for the completion of its life cycle occur together at greater depths. Admittedly, the population density of the second intermediate host(s) - various species of amphipod crustaceans - is lower than in shallow water. But even the total absence of these hosts should not disrupt the life cycle of $P$. atomon because the heavily infested final hosts, in particular flatfish, should secure infestations of the first intermediate host in deep water. As in $H$. elongata, the low water temperatures prevailing at the sea bottom may affect development, hatching success and invasive capacity of the miracidium of $P$. atomon and thus explain the absence of this trematode from deep-water littorines. Therefore, the penetration of $P$. atomon into the inner Baltic by means of brackish-water submergence appears to be precluded solely by the temperature-caused inactivation of its miracidial stage.

In conclusion, brackish-water submergence appears to be ecologically advantageous for bird trematodes employing highly motile animals such as fish as second intermediate hosts (as is the case in C. lingua), but to be disadvantageous for bird parasites that rely upon dispersal by an invertebrate host incapable of vertical migration in the open water (as is the case in M. pygmaeus).

Work is in progress to determine whether the observed brackish-water submergence of $C$. lingua and $M$. pygmaeus in Baltic waters is a constant phenomenon.

Acknowledgements. I am grateful to $\mathrm{M}$. Söhl for technical assistance and for preparing the figure. $\mathrm{H}$. Lauckner assisted with the collection of the material and typed the manuscript.

\section{LITERATURE CITED}

Deblock, S. \& Tran Van Ky, P., 1966. Contribution à l'étude des Microphallidae Travassos, 1920 (Trematoda). XII. Espèces d'Europe occidentale. Création de Sphairiotrema nov. gen.; considérations diverses de systématique. - Annls Parasit. hum. comp. 41, 23-60.

Guildal, J. A., 1964. Some qualitative and quantitative investigations on the endoparasitic fauna of the Scandinavian population of the black-headed gull (Larus ridibundus L.). - Int. Congr. Parasit, 1, 517-519.

Guildal, J. A., 1968. Investigations on the endoparasitic fauna of the Scandinavian - Baltic population of the herring gull. - Arsskr. K. Vet-Landbohøjsk. 1968, 59-78.

Jägerskiöld, L. A., 1900. Levinsenia (Distomum) pygmaea Levinsen, ein genitalnapftragendes Distomum. - Zbl. Bakt. ParasitKde (Abt. 1) 27, 732-740.

James, B. L., 1968. Studies on the life-cycle of Microphallus pygmaeus (Levinsen, 1881) (Trematoda: Microphallidae). - J, nat. Hist. 2, 155-172.

Lauckner, G., 1980. Diseases of Mollusca: Gastropoda. In: Diseases of marine animals. Ed. by O. Kinne. Wiley, Chichester, 1, 311-424.

Lauckner, G. 1984. Impact of trematode parasitism on the fauna of a North Sea tidal flat. Helgoländer Meeresunters. 37, 185-199.

Levinson, G. M. R., 1881. Bidrag til kundskab om Grønlands trematodfauna. - Overs. K. danske Vidensk. Selsk. Forh. 1, 52-84.

Linton, E., 1940. Trematodes from fishes mainly from the Woods Hole region, Massachusetts. - Proc. U.S. natn. Mus. 88, 1-172.

Möller, H., 1974. Untersuchungen über die Parasiten der Flunder (Platichthys flesus L.) in der Kieler Förde. - Ber. dt. wiss. Kommn Meeresforsch. 23, 136-149.

Möller, H., 1975a. Parasitological investigations on the European eelpout (Zoarces viviparus L.) in the Kiel Fjord (western Baltic). - Ber. dt. wiss. Kommn Meeresforsch. 24, 63-70.

Möller, H., 1975b. Die Parasiten des Dorsches (Gadus morhua L.) in der Kieler Förde. - Ber. dt. wiss. Kommn Meeresforsch. 24, 71-78.

Moller, $H$, 1978. The effects of salinity and temperature on the development and survival of fish parasites. - J. Fish Biol, 12, 311-323. 
Reimer, L. W, 1964. The salt contents - a factor determining the development of fish-and bird trematodes in the middle Baltic Sea. - Parasit. worms aquat. Condit. Prague, 1962, 63-68.

Reimer, L. W., 1970. Digene Trematoden und Cestoden der Ostseefische als natürliche Fischmarken. - Parasit. SchrReihe, 20, 1-144.

Remane, A., 1940. Einführung in die zoologische Okologie der Nord- und Ostsee. - Tierwelt Nordu. Ostsee 1a, 1-238.

Remane, A., 1955. Die Brackwasser-Submergenz und die Umkomposition der Coenosen in Beltund Ostsee. - Kieler Meeresforsch. 11, 59-73.

Rumsey, T. J., 1973. Some aspects of osmotic and ionic regulation in Littorina littorea (L.) (Gastropoda, Prosobranchia). - Comp. Biochem. Physiol. 45A, 327-344.

Sindermann, C. J. \& Farrin, A. E., 1962. Ecological studies of Cryptocotyle lingua (Trematoda: Heterophyidae) whose larvae cause 'pigment spots' of marine fish. - Ecology 43,69-75.

Sindermann, C. J. \& Rosenfield, A., 1954. Diseases of fishes of the western North Atlantic. III. Mortalities of sea herring (Clupea harengus) caused by larval trematode invasion. - Res. Bull. Maine Dep. Sea Shore Fish. 21, 1-16.

Stunkard, H. W. \& Shaw, C. R., 1931. The effect of dilution of sea water on the activity and the longevity of certain marine cercariae, with descriptions of two new species. - Biol. Bull. mar. biol. Lab., Woods Hole 61, 242-271.

Todd, M. E., 1964. Osmotic balance in Littorina littorea, L. littoralis and L. saxatilis (Littorinidae). Physiol. Zool. 37, 33-44.

Werding, B., 1969. Morphologie, Entwicklung und Okologie digener Trematoden-Larven der Strandschnecke Littorina littorea. - Mar. Biol. 3, 306-333. 